\title{
Tocilizumab-induced unexpected increase of several inflammatory cytokines in critically ill COVID-19 patients
}

Fanny Ponthieux ( $\sim$ Fanny.Ponthieux@lhub-ulb.be )

LHUB-ULB https://orcid.org/0000-0002-9831-2218

Nicolas Dauby

Centre Hospitalier Universitaire Saint-Pierre

Evelyne Maillart

Centre Hospitalier Universitaire Saint-Pierre

Jean-François Fils

Centre Hospitalier Universitaire Saint-Pierre

Julie Smet

Centre Hospitalier Universitaire Saint-Pierre

Marc Claus

Centre Hospitalier Universitaire Saint-Pierre

Tatiana Besse-Hammer

Centre Hospitalier Universitaire Saint-Pierre

David De Bels

Centre Hospitalier Universitaire Saint-Pierre

Francis Corazza

Centre Hospitalier Universitaire Saint-Pierre

Carole Nagant

Centre Hospitalier Universitaire Saint-Pierre

\section{Research Article}

Keywords: Inflammation, cytokines, IL-6, Tocilizumab, COVID-19, SARS-CoV-2 infection

Posted Date: February 23rd, 2021

DOI: https://doi.org/10.21203/rs.3.rs-234733/v1

License: (c) (i) This work is licensed under a Creative Commons Attribution 4.0 International License. Read Full License 


\section{Abstract}

Early evidence during the COVID-19 pandemic indicated high levels of IL-6 in patients with severe COVID-19. This led to the off-label use of tocilizumab (TCZ) during the first wave of the pandemic.

We aimed to monitor IL-6 and several inflammatory cytokines in critically ill COVID-19 patients receiving off-label TCZ. Fifteen critically ill SARS-CoV-2 PCR confirmed cases were enrolled and serum samples were collected during 8 days, before and following administration of a single dose of TCZ. In parallel, a control group consisting of 8 non-treated COVID-19 patients not receiving TCZ was established. Serum profile of 12 cytokines (IL-1 $\beta,-2,-4,-6,-8,-10,-12,-13,-17,-18, T N F-a$ and INF- $Y$ ) and of IL-6R were assessed in these two groups.

Although the increased IL- 6 concentrations after TCZ infusion were expected, we observed an unexpected increase in IL-1 $1 \beta$, $-2,-4,-10,-12 p 70,-18$ and IL-6R levels in the treated patients with maximal values reached 2 to 4 days after TCZ. In contrast, no change in cytokine levels was observed in the control group. There was no significant difference in cytokine levels between survivors (TCZ/S) or non-survivors (TCZ/D).

This observation suggests that some inflammatory pathways escape IL-6R blockade leading to an increase in several proinflammatory cytokines. Our findings could highlight an anti-inflammatory role of IL-6 and may explain why TCZ has failed to improve survival in critically ill COVID-19 patients when given alone.

\section{Introduction}

More than 30 years have passed since discovery, cloning and understanding of the biological role of interleukine-6 (IL-6) [1]. The IL- 6 signaling and its role in pathologies is currently well established and follow two different pathways involving the IL6 receptor (IL-6R) and the glycoprotein130 (gp130) [1]. The role of IL-6 dysregulation in various auto-immunes and inflammatory diseases has been the rationale to target its pathway and led to the first antibody designed to block IL-6R: Tocilizumab (TCZ) $[2,3]$. TCZ is a humanized monoclonal antibody directed against both the soluble form and membranebound IL-6R and blocks the IL-6 signal pathway through competitive inhibition of the receptor [3,4]. It was first introduced in Japan in 2008 followed by the European Union in 2009, under the name of RoActemra ${ }^{\circledR}$, and the USA in 2010 as Actemra ${ }^{\circledR}$, now licensed for use in more than one hundred countries for treatment of rheumatoid arthritis, juvenile idiopathic arthritis or Castleman's disease $[2,3,4]$.

From the beginning of the current pandemic, TCZ has been proposed in an off-label application to manage critical cases of Coronavirus Disease 2019 (COVID-19) and has quickly been included in the Chinese treatment guidelines [5,6]. Numerous clinical trials are ongoing to determine the most relevant target and therapeutic strategy in the management of COVID-19. TCZ is the purpose of ongoing nationwide (COV-AID), European (TOCIVID-19 in Italy, TOCOVID-19 in Spain) and international clinical trials (COVIDOSE in USA, TACOS in China), registered on clinicaltrials.gov. The optimal moment of administration for maximal therapeutic effect and the efficacy and safety of TCZ is still under investigation $[7,8,9]$.

Furthermore, the genuine effect of this drug on the cytokine storm remains poorly described $[9,10]$.

In this context, we aimed to monitor IL- 6 and several other inflammatory cytokines in critically ill COVID-19 patients before and during 8-days following anti-IL-6 therapy administration.

\section{Material And Methods}

\section{Study design}

Fifteen patients admitted to the CHU Saint-Pierre and Brugmann (Brussels, Belgium) between 18 March and 6 May 2020 with a diagnosis of COVID-19 and who received TCZ were included in our study. TCZ treated patients were further divided in 
two categories, patients who survived (TCZ/S, n=6) and non-survivors (TCZ/D, $n=9)$. We performed serum sample collections and follow-up measurements during 8 days post TCZ infusion.

In parallel, baseline cytokine levels were measured at the admission and during the following 8 days in 8 patients with COVID-19 who did not receive TCZ.

A median of 3 serum sample were analyzed for each patient.

Overall, 23 patients with a confirmed diagnosis of COVID-19 by a real-time polymerase chain reaction (RT-PCR) assay on a nasopharyngeal swab were enrolled.

Patients were classified as severe or critical illness according to WHO guidelines (2020).

Demographics and clinical data were collected from the medical file.

TCZ was administrated in a single intravenous dose of $8 \mathrm{mg} / \mathrm{kg}$, except for one patient who benefitted from a second one. All patients were treated with the standard pharmacological protocol including $2400 \mathrm{mg}$ of hydroxychloroquine in monotherapy over 5 days [11].

The study was approved by the local Ethical Committee of the CHU Brugmann (CE 2020/63) and Saint-Pierre (Reference CE/20-03-05) Hospitals and registered on clinicaltrials.gov as NCT04346017.

\section{Cytokine measurements}

The levels of 12 cytokines (IL-1 $13,-2,-4,-6,-8,-10,-12,-13,-17,-18$, TNF- $a$ and INF- $\gamma$ ) and of the IL-6R were assessed in the serum of patients using an electrochemiluminescence plate-based assay (MSD, Meso Scale Discovery, MD, USA).

\section{Laboratory findings}

Circulating inflammatory biomarkers levels (C-reactive protein (CRP), procalcitonin (PCT), ferritine, fibrinogen, d-dimers and neutrophils) were measured before TCZ administration and during 8 days following the treatment or admission using a Cobas 8000 Platform (Roche Diagnostics), a Sysmex CS-5100 analyzer (Siemens Healthcare Diagnostics) and a Lumipulse G600Il analyzer (Fujirebio).

\section{Statistical analysis}

A linear mixed model was used to analyze the evolution of cytokines over the time [12]. For each model, a group effect and a time effect were tested. When the residuals of the model were not normally distributed, we used the bestNormalize $\mathrm{R}$ package to transform the outcome, and reported the results of this last linear mixed model.

\section{Results}

Fifteen patients receiving TCZ further divided into two groups : survivors (TCZ/S group $(n=6)$ ) and non-survivors (TCZ/D group $(n=9))$, and 8 controls were followed for cytokine measurement.

There was no statistically significant difference according to the sex, the age and the state of illness between subgroups (Table 2). The median delay time between symptoms onset and hospital admission was of 7 days in the three groups. The median (min-max) time before administration of TCZ was of 9 days (5-23) since symptoms emergence, 5 days (1-10) since hospital admission and 3 days (1-7) since intensive care unit (ICU) admission, without significant difference between the TCZ/S and TCZ/D group (Table 2). 
Kinetics of cytokines were assessed during 8 days before and after TCZ administration (Figure1). Longitudinal changes in cytokines levels were analyzed using a linear mixed model and showed a significant transient effect (time ${ }^{2}$ effect) over time with a peak value reached around day 2 to 4 for IL-2 (only in TCZ/D ), $-4,-6,-6 R$ (only in TCZ/S), $-12,-13$ and TNFa (only in TCZ/D).

The maximum levels obtained for each cytokine were compared between groups (Table 1).

First regarding IL-6, concentrations rapidly rised in treated patients and remained high but gradually decreasing over the 8 days following the treatment injection. Moreover, significantly higher levels of IL-1 $\beta,-2,-4,-6 R,-10,-12 p 70$, and -18 were observed in patients receiving TCZ compared to the control group. These levels were elevated both in the TCZ/S group and the TCZ/D group, except for IL-4 and -10 which reached significantly higher values only in the TCZ/D group and for IL-6R. However, no statistically significant difference was observed in maximal values between the TCZ/S group and the TCZ/D group for the different cytokines.

Furthermore, the time associated with the maximal values of cytokines levels was not significantly different between the TCZ/S and TCZ/D groups.

The laboratory baseline results revealed high levels of inflammatory markers including CRP, ferritin, fibrinogen and neutrophils for all patients enrolled. Most of them remained stable in the non-treated group during the 8 days of follow-up. In the treated patients, CRP and fibrinogen levels improved and decreased toward the normal range while neutrophils and ferritin remained high above normal values, and d-dimers even increased in the TCZ/D group (Table 2).

\section{Discussion}

The cytokine profile of some critically ill COVID-19 patients shares similarities to those observed in cytokine release syndromes, characterized by an increased production of cytokines followed by the dysregulation of tissue repair mechanisms, damages and, finally, multiple organ failure leading to death $[6,9,13]$. Recently, levels of IL-6 have been included to the criteria for COVID-19 associated hyperinflammatory syndrome [14]. Cytokines IL- 6 and TNF-a have revealed to predict severity and mortality in COVID-19 [15]. Although the nature of the inflammation in COVID-19 is still poorly understood, immunomodulatory agents have rapidly been proposed and included into various clinical trials, most of them focused on IL-1 $\beta,-6,-8$ and TNF-a $[2,8,15]$.

In this study, we explored the longitudinal cytokine profile in critically ill SARS-CoV2 infected patients receiving anti-IL6R therapy. We focused on the trend of 12 inflammatory cytokines (IL-1 $\beta,-2,-4,-6,-8,-10,-12,-13,-17,-18$, TNF- $\alpha$ and INF- $\gamma$ ) and of the IL-6R in the treated group compared to patients without anti-cytokine therapy (Figure 1).

In the non-treated group, the cytokines and IL-6R levels remained stable over the 8 days following of the disease course, based on a longitudinal analysis, supporting previously reported results [15]. In the treated patients, we confirmed the expected rapid increase of IL-6 levels after TCZ injection followed by a gradual decrease [15]. This can be explained by the drug saturation of the receptor resulting in the inhibition of IL-6R-mediated consumption of IL- 6 by internalization $[4,8]$. This elevation could also reflect the endogenous IL-6 production related to the disease activity [16].

In parallel, the accumulation of TCZ/IL-6R complexes, may explain increased levels of IL-6R observed after TCZ injection as compared to non-treated group (Table 1).

We also observed a transient but significant increase in IL-2, -4, -6 -12,-13 (only in TCZ/D), TNF-a (only in TCZ/D) and IL-6R (only in TCZ/S), for patients receiving a single dose of IL-6R blockade therapy. This observation highlights that neutralization of the IL-6R pathway is not sufficient to completely prevent activation of all the inflammatory pathways. Our findings are in accordance with the Del Valle et al [15] previous observations on TCZ effect on IL-6 and -8 levels, whereas we 
diverge about the profile of TNF-a presenting a transient increase following the treatment injection, as seen only in the TCZ/D group in our study.

IL-6 signal transduction acts through both a soluble and membrane-bound receptor involved in two different pathways with divergent functions: the classical one promoting anti-inflammatory responses and the trans-signaling pathway responsible for the pro-inflammatory effects $[1,4,6]$. TCZ acts by blocking both of them and thus inhibits pro- but also potentially protective anti-inflammatory IL-6 mediated responses.

In contrast to cytokines, circulating inflammatory biomarkers such as CRP, fibrinogen and ferritin baseline levels were elevated but decreased shortly after TCZ administration, without any difference between survivors and non-survivors patients (Figure 2). These laboratory findings corroborate with previous results of Toniati et al [17], with a decrease of these biomarkers toward a normal range associated with a clinical improvement 10 days after TCZ. However, we noticed an increase in neutrophils and d-dimer levels in our treated population and especially in non-survivors, comforting that IL-6 pathway blockers act only partially on the inflammatory cascade. While the ferritin profile was stable over our follow-up time in all three groups, it remained above normal values.

In summary, on one hand, some inflammatory biomarkers rapidly decreased in the 8 days following TCZ infusion and, on the other hand, levels of several inflammatory cytokines significantly increased after a single dose of TCZ, suggesting a partial effect on hyperinflammation. These findings enhance the pivotal role of the IL-6 pathway : it may have a downregulatory effect on several cytokines that disappears by blocking the binding of IL-6 to its receptor, resulting in an increased production of these cytokines.

This incomplete inhibition of the inflammatory response, shortly after one dose of TCZ, might explain why most clinical trials failed to meet their primary endpoints of improved clinical status in COVID-19 patients $[8,18]$. Meanwhile, recent results suggest that IL-6R blockade could decrease the mortality in critically ill patients especially when standard of care included other anti-inflammatory treatment such as dexamethasone $[18,19,20]$. The increased levels of several inflammatory cytokines observed after a single TCZ administration in SARS-CoV-2 infected patients might also explain why immunomodulatory therapies with a wider range of targets proved to be more efficient, as suggested by the benefit of dexamethasone use in the preliminary results of the RECOVERY study [20]. Combined to dexamethasone, TCZ has proved to decrease the composite outcome of mechanical ventilation or death [21]. The nationwide Belgian COV-AID trial that compares combination of anti-IL-6 and IL-1 blockade in patients with COVID-19 associated hyperinflammatory syndrome will provide an answer about the clinical benefit of targeting multiple inflammatory pathways [22].

Our work features several limitations and particularly the limited number of patients included in the study, which may explain why we could not observe a difference between survivors and non-survivors TCZ-treated patients.

Recently Azmy et al. suggested that TCZ was unable to calm the inflammatory storm by observing increased IL10 and IL2 receptor levels in patients receiving TCZ [23]. Our study is, to our knowledge, the first to monitor such a large panel of inflammatory cytokines immediately after administration of TCZ in patients with critical COVID-19. . Besides the predictable peak of IL-6 concentration, we highlight an immune dysregulation worsening after TCZ injection as evidenced by the increase of several others cytokines, among them some pro-inflammatory and potentially harmful ones. These findings suggest that the IL-6 inhibition alone may not be sufficient to completely block the hyperinflammatory state described in critically ill COVID-19 patients and that more investigations are required to correlate these biological results with a potential clinical outcome. This observation may constitute an argument pleading for a treatment that target more broadly the various pathways of inflammation. It could also explain why most of the studies in which a positive effect of TCZ has been observed included corticosteroids [5,11].

\section{Declarations}




\section{Conflict of interest}

The authors declare no conflicts of interests

\section{Acknowledgements}

We thank Asma Benslimane and Thao Tran Thi Thanh for their technical help. N.D. is a post-doctorate clinical master specialist of the F.R.S-FNRS.

\section{Author contributions}

Concept and design: CN, FC, FP, JS

Analysis and interpretation of cytokine data: CN, FC, JF.

Patient enrollment and collection of clinical data: ND, EM, DD, TB

Writing original draft: FP, CN

All authors critically reviewed the manuscript.

\section{References}

[1] L.H. Calabrese, S. Rose-John, IL-6 biology: Implications for clinical targeting in rheumatic disease, Nat. Rev. Rheumatol. 10 (2014) 720-727. https://doi.org/10.1038/nrrheum.2014.127.

[2] E.H. Choy, F. De Benedetti, T. Takeuchi, M. Hashizume, M.R. John, T. Kishimoto, Translating IL-6 biology into effective treatments, Nat. Rev. Rheumatol. 16 (2020) 335-345. https://doi.org/10.1038/s41584-020-0419-z.

[3] M. Sheppard, F. Laskou, P.P. Stapleton, S. Hadavi, B. Dasgupta, Tocilizumab (actemra), Hum. Vaccines Immunother. 13 (2017) 1972-1988. https://doi.org/10.1080/21645515.2017.1316909.

[4] J. Wolf, S. Rose-John, C. Garbers, Interleukin-6 and its receptors: a highly regulated and dynamic system, Cytokine. 70 (2014) 11-20. https://doi.org/10.1016/j.cyto.2014.05.024.

[5] J.M. Sanders, M.L. Monogue, T.Z. Jodlowski, J.B. Cutrell, Pharmacologic Treatments for Coronavirus Disease 2019 (COVID-19): A Review, JAMA - J. Am. Med. Assoc. 323 (2020) 1824-1836. https://doi.org/10.1001/jama.2020.6019.

[6] A. Yarmohammadi, M. Yarmohammadi, S. Fakhri, H. Khan, Targeting pivotal inflammatory pathways in COVID-19: A mechanistic review, Eur. J. Pharmacol. 890 (2021) 173620. https://doi.org/10.1016/j.ejphar.2020.173620.

[7] L. De Stefano, F. Bobbio-Pallavicini, A. Manzo, C. Montecucco, S. Bugatti, A “Window of Therapeutic Opportunity” for AntiCytokine Therapy in Patients With Coronavirus Disease 2019, Front. Immunol. 11 (2020).

https://doi.org/10.3389/fimmu.2020.572635.

[8] S. Khiali, E. Khani, T. Entezari-Maleki, A Comprehensive Review of Tocilizumab in COVID-19 Acute Respiratory Distress Syndrome, J. Clin. Pharmacol. 60 (2020) 1131-1146. https://doi.org/10.1002/jcph.1693.

[9] Y. Tang, J. Liu, D. Zhang, Z. Xu, J. Ji, C. Wen, Cytokine Storm in COVID-19: The Current Evidence and Treatment Strategies, Front. Immunol. 11 (2020) 1-13. https://doi.org/10.3389/fimmu.2020.01708.

[10] D.E. Leisman, L. Ronner, R. Pinotti, M.D. Taylor, P. Sinha, C.S. Calfee, A. V. Hirayama, F. Mastroiani, C.J. Turtle, M.O. Harhay, M. Legrand, C.S. Deutschman, Cytokine elevation in severe and critical COVID-19: a rapid systematic review, meta- 
analysis, and comparison with other inflammatory syndromes, Lancet Respir. Med. 8 (2020) 1233-1244. https://doi.org/10.1016/S2213-2600(20)30404-5.

[11] L. Catteau, N. Dauby, M. Montourcy, E. Bottieau, J. Hautekiet, E. Goetghebeur, S. van lerssel, E. Duysburgh, H. Van Oyen, C. Wyndham-Thomas, D. Van Beckhoven, K. Bafort, L. Belkhir, N. Bossuyt, P. Caprasse, V. Colombie, P. De Munter, J.

Deblonde, D. Delmarcelle, M. Delvallee, R. Demeester, T. Dugernier, X. Holemans, B. Kerzmann, P. Yves Machurot, P. Minette, J.M. Minon, S. Mokrane, C. Nachtergal, S. Noirhomme, D. Piérard, C. Rossi, C. Schirvel, E. Sermijn, F. Staelens, F. Triest, N. Van Goethem, J. Van Praet, A. Vanhoenacker, R. Verstraete, E. Willems, Low-dose hydroxychloroquine therapy and mortality in hospitalised patients with COVID-19: a nationwide observational study of 8075 participants, Int. J. Antimicrob. Agents. 56 (2020). https://doi.org/10.1016/j.ijantimicag.2020.106144.

[12] Verbeke G, Molenberghs G. Linear Mixed Models for Longitudinal Data. Springer Series in Statistics. New-York: SpringerVerlag; 2000.

[13] L.Y.C. Chen, R.L. Hoiland, S. Stukas, C.L. Wellington, M.S. Sekhon, Confronting the controversy: Interleukin-6 and the COVID-19 cytokine storm syndrome, Eur. Respir. J. 56 (2020). https://doi.org/10.1183/13993003.03006-2020.

[14] B.J. Webb, I.D. Peltan, P. Jensen, D. Hoda, B. Hunter, A. Silver, N. Starr, W. Buckel, N. Grisel, E. Hummel, G. Snow, D. Morris, E. Stenehjem, R. Srivastava, S.M. Brown, Clinical criteria for COVID-19-associated hyperinflammatory syndrome: a cohort study, Lancet Rheumatol. 2 (2020) e754-e763. https://doi.org/10.1016/S2665-9913(20)30343-X.

[15] D.M. Del Valle, S. Kim-Schulze, H.H. Huang, N.D. Beckmann, S. Nirenberg, B. Wang, Y. Lavin, T.H. Swartz, D. Madduri, A. Stock, T.U. Marron, H. Xie, M. Patel, K. Tuballes, O. Van Oekelen, A. Rahman, P. Kovatch, J.A. Aberg, E. Schadt, S. Jagannath, M. Mazumdar, A.W. Charney, A. Firpo-Betancourt, D.R. Mendu, J. Jhang, D. Reich, K. Sigel, C. Cordon-Cardo, M. Feldmann, S. Parekh, M. Merad, S. Gnjatic, An inflammatory cytokine signature predicts COVID-19 severity and survival, Nat. Med. 26 (2020) 1636-1643. https://doi.org/10.1038/s41591-020-1051-9.

[16] N. Nishimoto, K. Terao, T. Mima, H. Nakahara, N. Takagi, T. Kakehi, Mechanisms and pathologic significances in increase in serum interleukin-6 (IL-6) and soluble IL-6 receptor after administration of an anti-IL-6 receptor antibody, tocilizumab, in patients with rheumatoid arthritis and Castleman disease, Blood. 112 (2008) 3959-3964.

https://doi.org/10.1182/blood-2008-05-155846.

[17] P. Toniati, S. Piva, M. Cattalini, E. Garrafa, F. Regola, F. Castelli, F. Franceschini, P. Airò, C. Bazzani, E.A. Beindorf, M. Berlendis, M. Bezzi, N. Bossini, M. Castellano, S. Cattaneo, I. Cavazzana, G.B. Contessi, M. Crippa, A. Delbarba, E. De Peri, A. Faletti, M. Filippini, M. Frassi, M. Gaggiotti, R. Gorla, M. Lanspa, S. Lorenzotti, R. Marino, R. Maroldi, M. Metra, A. Matteelli, D. Modina, G. Moioli, G. Montani, M.L. Muiesan, S. Odolini, E. Peli, S. Pesenti, M.C. Pezzoli, I. Pirola, A. Pozzi, A. Proto, F.A. Rasulo, G. Renisi, C. Ricci, D. Rizzoni, G. Romanelli, M. Rossi, M. Salvetti, F. Scolari, L. Signorini, M. Taglietti, G. Tomasoni, L.R. Tomasoni, F. Turla, A. Valsecchi, D. Zani, F. Zuccalà, F. Zunica, E. Focà, L. Andreoli, N. Latronico, Tocilizumab for the treatment of severe COVID-19 pneumonia with hyperinflammatory syndrome and acute respiratory failure: A single center study of 100 patients in Brescia, Italy, Autoimmun. Rev. 19 (2020) 102568. https://doi.org/10.1016/j.autrev.2020.102568.

[18] B. Furlow, COVACTA trial raises questions about tocilizumab's benefit in COVID-19, Lancet Rheumatol. 2 (2020) e592. https://doi.org/10.1016/s2665-9913(20)30313-1.

[19] J.H. Stone, M.J. Frigault, N.J. Serling-Boyd, A.D. Fernandes, L. Harvey, A.S. Foulkes, N.K. Horick, B.C. Healy, R. Shah, A.M. Bensaci, A.E. Woolley, S. Nikiforow, N. Lin, M. Sagar, H. Schrager, D.S. Huckins, M. Axelrod, M.D. Pincus, J. Fleisher, C.A. Sacks, M. Dougan, C.M. North, Y.-D. Halvorsen, T.K. Thurber, Z. Dagher, A. Scherer, R.S. Wallwork, A.Y. Kim, S. Schoenfeld, P. Sen, T.G. Neilan, C.A. Perugino, S.H. Unizony, D.S. Collier, M.A. Matza, J.M. Yinh, K.A. Bowman, E. Meyerowitz, A. Zafar, Z.D. Drobni, M.B. Bolster, M. Kohler, K.M. D’Silva, J. Dau, M.M. Lockwood, C. Cubbison, B.N. Weber, M.K. Mansour, Efficacy of Tocilizumab in Patients Hospitalized with Covid-19, N. Engl. J. Med. (2020) 1-12. https://doi.org/10.1056/nejmoa2028836. 
[20] Dexamethasone in Hospitalized Patients with Covid-19 - Preliminary Report, N. Engl. J. Med. (2020) 1-11. https://doi.org/10.1056/nejmoa2021436.

[21] C. Salama, J. Han, L. Yau, W.G. Reiss, B. Kramer, J.D. Neidhart, G.J. Criner, E. Kaplan-Lewis, R. Baden, L. Pandit, M.L. Cameron, J. Garcia-Diaz, V. Chávez, M. Mekebeb-Reuter, ; Ferdinando, L. Menezes, R. Shah, M.F. González-Lara, B. Assman, J. Freedman, S. V Mohan, ; San, J.O. Associates, L. Katz, Tocilizumab in nonventilated patients hospitalized with Covid-19 pneumonia, MedRxiv. (2020) 2020.10.21.20210203. https://doi.org/10.1056/NEJMoa2030340.

[22] B. Maes, C. Bosteels, E. De Leeuw, J. Declercq, K. Van Damme, A. Delporte, B. Demeyere, S. Vermeersch, M. Vuylsteke, J. Willaert, L. Bollé, Y. Vanbiervliet, J. Decuypere, F. Libeer, S. Vandecasteele, I. Peene, B.N. Lambrecht, Erratum: Treatment of severely ill COVID-19 patients with anti-interleukin drugs (COV-AID): A structured summary of a study protocol for a randomised controlled trial (Trials (2020) 21468 DOI: 10.1186/s13063-020-04453-5), Trials. 21 (2020) 20-21. https://doi.org/10.1186/s13063-020-04519-4.

[23] V. Azmy, K. Kaman, D. Tang, H. Zhao, C. Dela Cruz, J.E. Topal, M. Malinis, C.C. Price, Cytokine Profiles Before and After Immune Modulation in Hospitalized Patients with COVID-19, J. Clin. Immunol. (2021). https://doi.org/10.1007/s10875-02000949-6.

\section{Tables}

Table 1 Cytokine profile in the three groups and comparison (maximum values, time associated with this maximum and time ${ }^{2}$ effect) 


\begin{tabular}{|c|c|c|c|c|c|c|c|c|c|}
\hline Variable & $\begin{array}{l}\text { No TCZ } \\
(\mathrm{N})\end{array}$ & $\begin{array}{l}\text { TCZ/dead } \\
\text { (D) }\end{array}$ & $\begin{array}{l}\text { TCZ/survivor } \\
\text { (S) }\end{array}$ & $\begin{array}{l}p- \\
\text { value } \\
\text { No } \\
\text { TCZ } \\
(\mathrm{N})\end{array}$ & $\begin{array}{l}p \text {-value } \\
\text { TCZ/dead } \\
\text { (D) }\end{array}$ & $\begin{array}{l}\text { p-value } \\
\text { TCZ } \\
\text { survivor } \\
\text { (S) }\end{array}$ & $\begin{array}{l}p \text {-value } \\
\text { N-D }\end{array}$ & $\begin{array}{l}p \text {-value } \\
\text { N-S }\end{array}$ & $\begin{array}{l}p- \\
\text { value } \\
\text { D-S }\end{array}$ \\
\hline IFN-g & $\begin{array}{l}81.5 \\
{[41.1-} \\
191.1]\end{array}$ & $\begin{array}{l}118.0 \\
{[34.6-} \\
244.8]\end{array}$ & $\begin{array}{l}137.92[91.1- \\
157.9]\end{array}$ & & & & 0.9776 & 0.8580 & 0.9374 \\
\hline $\begin{array}{l}\text { Time } \\
\text { IFN-g }\end{array}$ & $1.6 \pm 0.9$ & $\begin{array}{l}2.22 \pm \\
1.64\end{array}$ & $1.2 \pm 1.2$ & & & & 0.622 & 0.795 & 0.298 \\
\hline $\begin{array}{l}\text { Time }^{2} \\
\text { IFN-g }\end{array}$ & -0.0277 & -0.04545 & -0.0505 & 0.4997 & 0.0941 & 0.0712 & & & \\
\hline IL-10 & $3.8 \pm 2.8$ & $7.7 \pm 3.2$ & $5.3 \pm 2.1$ & & & & 0.0132 & 0.5351 & 0.1955 \\
\hline $\begin{array}{l}\text { Time IL- } \\
10\end{array}$ & $\begin{array}{l}2[1.8- \\
2.3]\end{array}$ & $1[0-3]$ & $0.5[0-1]$ & & & & 0.7121 & 0.0197 & 0.3793 \\
\hline $\begin{array}{l}\text { Time }^{2} \\
\text { IL-10 }\end{array}$ & -0.0315 & -0.0164 & -0.0153 & 0.4798 & 0.5284 & 0.6854 & & & \\
\hline $\begin{array}{l}\text { IL- } \\
12 p 70\end{array}$ & $\begin{array}{l}0.2[0.1- \\
3]\end{array}$ & $\begin{array}{l}2.8[1.3- \\
4.1]\end{array}$ & 2.6 [1.3-3.0] & & & & 0.0014 & 0.0003 & 0.8928 \\
\hline $\begin{array}{l}\text { Time IL- } \\
12 \text { p70 }\end{array}$ & $4.0 \pm 2.7$ & $2.8 \pm 1.6$ & $2.5 \pm 2.1$ & & & & 0.493 & 0.425 & 0.968 \\
\hline $\begin{array}{l}\text { Time }^{2} \\
\text { IL-12 }\end{array}$ & 0.00232 & -0.1054 & -0.0804 & 0.9141 & $<0.001$ & 0.0052 & & & \\
\hline IL-13 & $\begin{array}{l}1.1[0.9- \\
1.5]^{[}\end{array}$ & $\begin{array}{l}3.2[1.1- \\
8.4]\end{array}$ & $3.9[2.7-10.5]$ & & & & 0.1693 & 0.8889 & 0.8190 \\
\hline $\begin{array}{l}\text { Time IL- } \\
13\end{array}$ & $3.0 \pm 2.5$ & $2.1 \pm 1.7$ & $2.3 \pm 2.2$ & & & & 0.670 & 0.831 & 0.978 \\
\hline $\begin{array}{l}\text { Time }^{2} \\
\text { IL-13 }\end{array}$ & 0.0401 & -0.0606 & -0.0783 & 0.2634 & 0.0440 & 0.0847 & & & \\
\hline IL-1b & $\begin{array}{l}0.2[0.1- \\
0.4]\end{array}$ & $\begin{array}{l}1.2[1.1- \\
4.0]\end{array}$ & $1.7[0.7-2.9]$ & & & & 0.0027 & $<0.0001$ & 0.9632 \\
\hline $\begin{array}{l}\text { Time IL- } \\
\mathbf{1 b}\end{array}$ & $3.6 \pm 2.8$ & $3.0 \pm 2.3$ & $2.7 \pm 2.0$ & & & & 0.854 & 0.743 & 0.962 \\
\hline $\begin{array}{l}\text { Time }^{2} \\
\text { IL-1b }\end{array}$ & 0.00708 & -0.5643 & -0.0503 & 0.4105 & 0.1413 & 0.2896 & & & \\
\hline IL-2 & $\begin{array}{l}0.8[0.5- \\
1.1]\end{array}$ & $\begin{array}{l}4.3[3.0- \\
10.2]\end{array}$ & $\begin{array}{l}3.1[1.8- \\
4.3]\end{array}$ & & & & $<0.0001$ & 0.0012 & 0.4991 \\
\hline $\begin{array}{l}\text { Time IL- } \\
2\end{array}$ & $4.3 \pm 3.1$ & $1.8 \pm 1.8$ & $2.3 \pm 2.1$ & & & & 0.109 & 0.319 & 0.899 \\
\hline $\begin{array}{l}\text { Time }_{\text {IL-2 }}^{2} \\
\text { Th }\end{array}$ & 0.01871 & -0.0800 & -0.0486 & 0.5464 & 0.0180 & 0.1089 & & & \\
\hline $\mathrm{IL}-4$ & $0.2 \pm 0.4$ & $0.9 \pm 0.6$ & $0.7 \pm 0.4$ & & & & 0.0143 & 0.1308 & 0.7118 \\
\hline $\begin{array}{l}\text { Time IL- } \\
\mathbf{4}\end{array}$ & $3.5 \pm 2.9$ & $3.4 \pm 2.2$ & $2.3 \pm 2.1$ & & & & 0.999 & 0.656 & 0.669 \\
\hline $\begin{array}{l}\text { Time }^{2} \\
\text { IL-4 }\end{array}$ & 0.0112 & -0.0876 & -0.07305 & 0.7414 & 0.0015 & 0.0118 & & & \\
\hline IL-6 & 31.9 & 1265.5 & 1307.2 & & & & $<0.0001$ & $<0.0001$ & 0.7392 \\
\hline
\end{tabular}




\begin{tabular}{|c|c|c|c|c|c|c|c|c|c|}
\hline & $\begin{array}{l}{[19.2-} \\
55.4]\end{array}$ & $\begin{array}{l}{[854.9-} \\
1703.9]\end{array}$ & $\begin{array}{l}{[731.0-} \\
1555.2]\end{array}$ & & & & & & \\
\hline $\begin{array}{l}\text { Time IL- } \\
6\end{array}$ & $3.8 \pm 2.1$ & $3.6 \pm 2.1$ & $2.0 \pm 1.3$ & & & & 0.977 & 0.242 & 0.304 \\
\hline $\begin{array}{l}\text { Time }_{\text {IL-6 }}^{2} \\
\text { I }\end{array}$ & 0.30104 & -550.488 & -473.472 & 0.7894 & 0.0024 & 0.0058 & & & \\
\hline IL-8 & $\begin{array}{l}89.1 \\
{[49.4-} \\
209.6]\end{array}$ & $\begin{array}{l}639.2 \\
{[165.4-} \\
2008.3]\end{array}$ & $\begin{array}{l}915.8[124.7- \\
1829.9]\end{array}$ & & & & 0.0531 & 0.1164 & 0.9620 \\
\hline $\begin{array}{l}\text { Time IL- } \\
\mathbf{8}\end{array}$ & $3.5 \pm 2.6$ & $2.9 \pm 2.4$ & $3.2 \pm 2.3$ & & & & 0.867 & 0.966 & 0.975 \\
\hline $\begin{array}{l}\text { Time }^{2} \\
\text { IL-8 }\end{array}$ & 0.04610 & -0.0435 & -0.0408 & 0.0767 & 0.0847 & 0.3051 & & & \\
\hline TNF-a & $7.6 \pm 5.4$ & $\begin{array}{l}18.6 \pm \\
12.4\end{array}$ & $15.8 \pm 7.6$ & & & & 0.0603 & 0.2509 & 0.8415 \\
\hline $\begin{array}{l}\text { Time } \\
\text { TNF-a }\end{array}$ & $2.9 \pm 2.4$ & $4.1 \pm 1.8$ & $4.5 \pm 2.9$ & & & & 0.532 & 0.418 & 0.947 \\
\hline $\begin{array}{l}\text { Time }^{2} \\
\text { TNFa }\end{array}$ & 0.00262 & -0.0698 & -0.0463 & 0.9480 & 0.0029 & 0.0745 & & & \\
\hline IL-6R & $\begin{array}{l}78830.6 \\
\pm \\
33553.27\end{array}$ & $\begin{array}{l}118244.5 \\
\pm 31209.7\end{array}$ & $\begin{array}{l}164354.2 \pm \\
59963.3\end{array}$ & & & & 0.1435 & 0.0028 & 0.1082 \\
\hline $\begin{array}{l}\text { Time IL- } \\
6 \mathrm{R}\end{array}$ & $\begin{array}{l}5.5[2- \\
6.3]\end{array}$ & $7[6-7]$ & $6[6-6]$ & & & & 0.4699 & 0.9294 & 0.5904 \\
\hline $\begin{array}{l}\text { Time }^{2} \\
\text { IL-6R }\end{array}$ & 0.00231 & -0.0196 & -0.07014 & 0.8880 & 0.1749 & 0.0397 & & & \\
\hline IL-17 & $\begin{array}{l}3.6[3.4- \\
10.8]\end{array}$ & $\begin{array}{l}3.9[2.7- \\
4.3]\end{array}$ & $6.3[5.2-12.6]$ & & & & 0.7736 & 0.5287 & 0.1789 \\
\hline $\begin{array}{l}\text { Time IL- } \\
17\end{array}$ & $\begin{array}{l}3.5[1.8- \\
6.3]\end{array}$ & $3[1.0-6]$ & $4.5[2.3-6]$ & & & & 0.9882 & 0.9661 & 0.9234 \\
\hline $\begin{array}{l}\text { Time }^{2} \\
\text { IL-17 }\end{array}$ & -0.01560 & -0.00660 & -0.0238 & 0.6790 & 0.6804 & 0.3399 & & & \\
\hline IL-18 & $\begin{array}{l}8620.0 \\
{[8253.1-} \\
10238.9]\end{array}$ & $\begin{array}{l}3487.3 \\
{[2711.8-} \\
3962.9]\end{array}$ & $2670.9[2535.4$ & $-4068.5]$ & & & 0.0003 & 0.0007 & 0.9203 \\
\hline $\begin{array}{l}\text { Time IL- } \\
18\end{array}$ & $4.4 \pm 2.3$ & $4.3 \pm 2.6$ & $2.3 \pm 2.2$ & & & & 0.999 & 0.267 & 0.264 \\
\hline $\begin{array}{l}\text { Time }^{2} \\
\text { IL-18 }\end{array}$ & -0.02105 & -0.01652 & -0.0181 & 0.5846 & 0.1189 & 0.2634 & & & \\
\hline
\end{tabular}

Table 2. Demographic and clinical characteristics in the three groups 


\begin{tabular}{|c|c|c|c|c|}
\hline \multirow[t]{2}{*}{ Variable } & & $\begin{array}{l}\text { NO TCZ } \\
(\mathrm{N})\end{array}$ & $\begin{array}{l}\text { TCZ/dead } \\
\text { (D) }\end{array}$ & $\begin{array}{l}\text { TCZ/survivors } \\
\text { (S) }\end{array}$ \\
\hline & & $\mathrm{n}=8$ & $\mathrm{n}=9$ & $\mathrm{n}=6$ \\
\hline Median age & (years) & 70 [31-91] & $65[44-84]$ & $48,5[41-74]$ \\
\hline Gender & Male & $6(75 \%)$ & $7(77,8 \%)$ & $4(66,7 \%)$ \\
\hline \multirow[t]{2}{*}{ State off illness } & Severe & $3(37,5 \%)$ & - & - \\
\hline & Critical & $5(62,5 \%)$ & $9(100 \%)$ & $6(100 \%)$ \\
\hline \multirow[t]{2}{*}{ Hospitalization days } & Total & $\begin{array}{l}43,5[5- \\
137]\end{array}$ & $25[5-57]$ & $53,5[24-134]$ \\
\hline & $I C U$ & $7,5[0-49]$ & $27[11-56]$ & $43,5[12-65]$ \\
\hline $\begin{array}{l}\text { Time between onset of symptoms and hospital } \\
\text { admission }\end{array}$ & (days) & $7[1-21]$ & $7[4-14]$ & $7[1-13]$ \\
\hline Time between onset of symptoms and ICU admission & (days) & $10,5[4-15]$ & $9[5-15]$ & $11,5[1-15]$ \\
\hline Time between onset of symptoms and TCZ infusion & (days) & - & $11[8-23]$ & 14 [11-18] \\
\hline Time between hospital admission and TCZ infusion & (days) & - & $4[1-5]$ & $6[4-10]$ \\
\hline Time between ICU admission and TCZ infusion & (days) & - & $2[0-8]$ & $3,5[1-10]$ \\
\hline
\end{tabular}

Data are expressed as median [min-max] or $\mathrm{n}(\%)$. TCZ : tocilizumab; ICU : intensive care unit.

Figures 

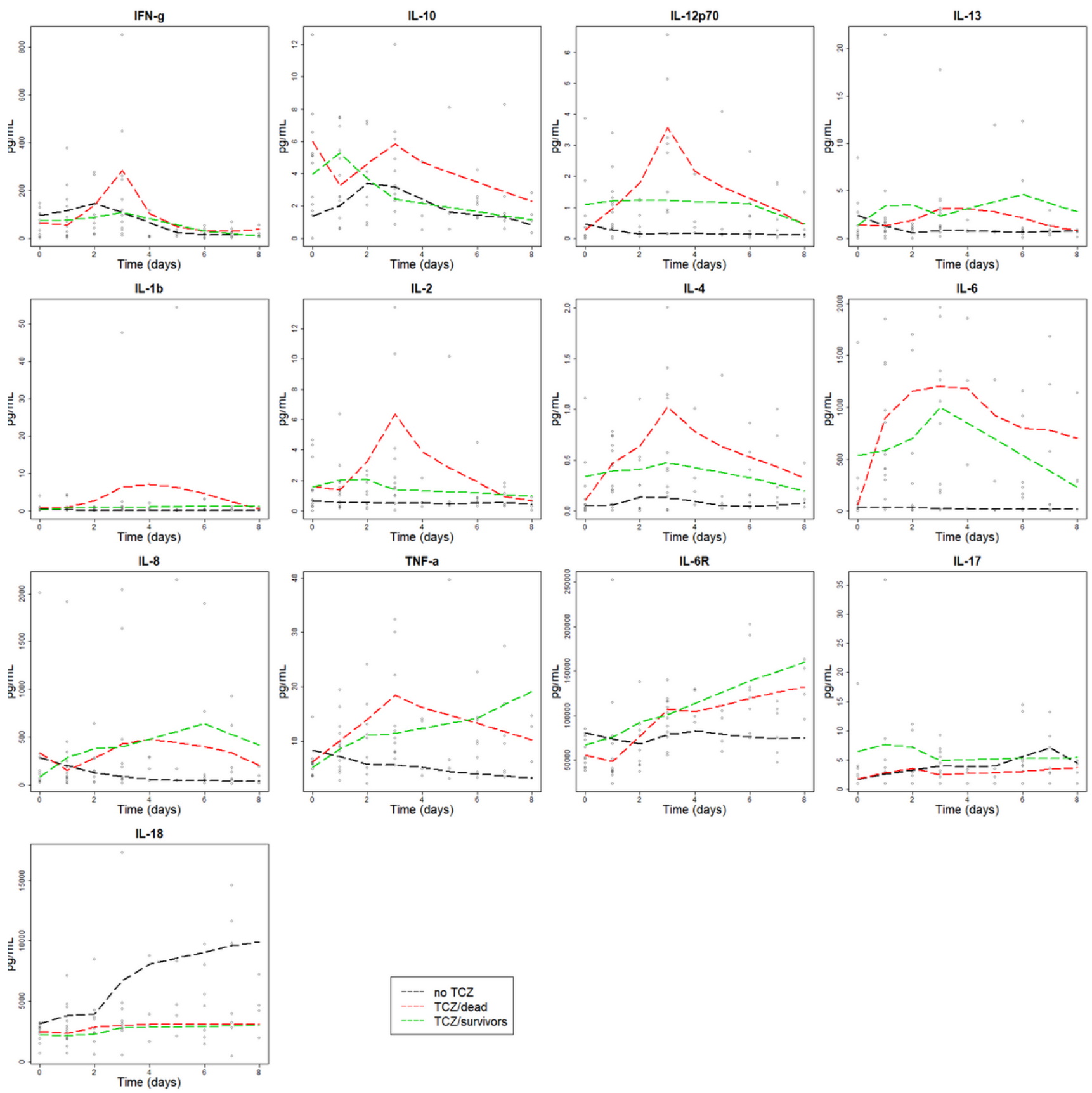

\section{Figure 1}

Kinetics of cytokines in the three groups Kinetics of IL-1 $\beta,-2,-4,-6,-8,-10,-12,-13,-17,-18$, TNF- $a$ and INF- $\gamma$ in non-treated (NO TCZ, n=8) versus treated survivors (TCZ/S, $n=6$ ) or treated non-survivors (TCZ/D, n=9). Results were measured between day 0 and day 8 after TCZ infusion, or from hospital admission for the NO TCZ group. 

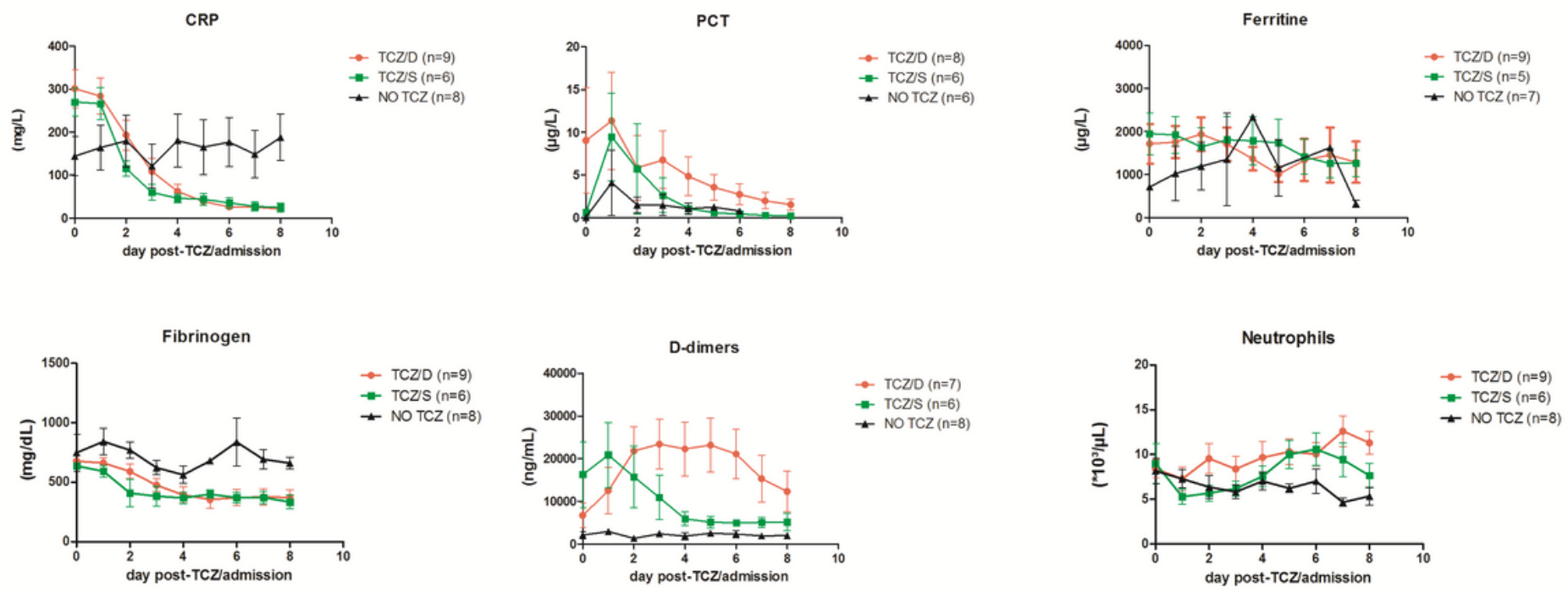

\section{Figure 2}

Treatment effect on circulating inflammatory biomarkers Kinetics of C-reactive protein (CRP), procalcitonin (PCT), ferritine, fibrinogen, d-dimers and neutrophils* levels in non-treated (NO TCZ, n=8) versus treated survivors (TCZ/S, $n=6)$ and treated non-survivors (TCZ/D, n=9). Results were measured between day 0 and day 8 after TCZ infusion, or from hospital admission for the NO TCZ group. Results are presented as mean +/- SEM. *Not all patient received all relevant laboratory tests. 